\title{
樹姿を異にした茶樹の品種の仕立て法
}

\author{
静岡県茶業試験場
}

此本晴夫・木村政美

\section{Method of Frame Formation Conformed to Varietal \\ Differences in Plant Shape of Tea}

\section{By Haruo Konomoto and Masami Kimura \\ Shizuoka Tea Experiment Station}

\section{1 はじめに}

生産過剩基調下に括ける茶業の安定化を図るために は，需要の桩大が必要である。そのためには優良品種を 導入し，良質な茶を安く生産することが重要である。現 在, 品種化は進みつつあるが，その多くはやぶきたであ る。やぶきた一边倒礼なと，摘採期が集中し，摘採労 力の問題や工場運営に支障をきたすことが心配される。 また品種が単一化すると品質が似たすのとなる。一方， 消費者の恅好は多様化してきているといわれる。消費の 拡大を図るためには，变化（バラエティー）に富んだ品 質のものを消費者に提供していくことも必要と思われ る。そのためには，やぶきた以外の品種の導入が必要で ある。

しかし，現在の栽培技術体系や製造法は，やぶきたを 中心作られたるのであるので，他の品種に必ずしる適 しているとはい充ない。やぶきた外の品種の栽培面皘 を增すためには，品種に適した栽培法や製造法の確立が 必要である。

そのため，1976年から 3 力年農林水産省の総合助成を 受けて，品種に適した栽培法の試験を行ってきた。その 一つとして，樹姿を異にした品種の仕立て法について検
討した。

幼木園の仕立てには，多くの要因が関係するすのと思 われる。ここでは，澍姿を異とする 3 品種を用い，定植 時のせん枝の高さと 2 年目のせん枝の高さを組合せて試 験を行った。

定植当年から 5 カ年の結果をとりまとめて報告する。

\section{2 試 験 方 法}

\section{1 栽植方法および供試苗の生育状態}

1976年 3 月16 18日飞， 3 品種の 2 年生苗を用い， 3 ね幅 $1.8 \mathrm{~m}$ ，株間 $0.3 \mathrm{~m}$ の単条植えとして定植した。 供試した苗の生育状況は表1のと拈りである。

\section{2 試験区の構 成}

取り上げた要因と水準は表 2のと㐨りである。これら を直交表 $\mathrm{L}_{27}$ に割り付けて試験を行った。せん枝処理の 時期は表 3 に，摘採，整枝は表 4 に示したよ 5 な方法で 行った。

\section{3 生育および収量調查}

定植当年から 3 力年は， 5 月と 11 月の 2 回，樹高，株 張り, 分枝数, 幹径 (定植後 2 年間), 世九枝量などにつ いて調查した。

4 年目以後は， 5 月と11月に椡高と株張りについて調

表1供試苗の生育状況（1品種 20株平均）

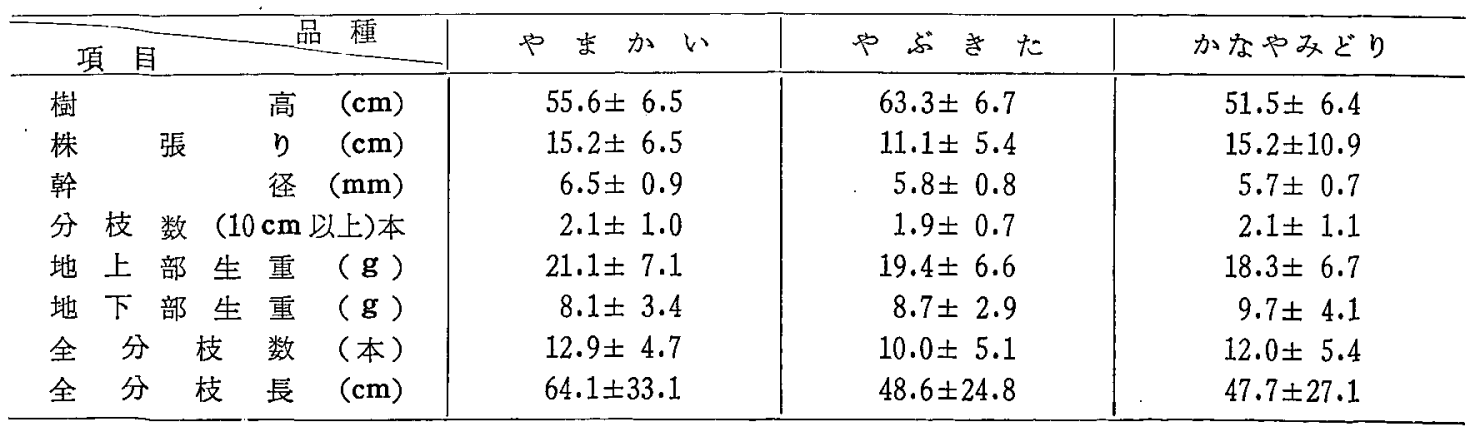


表2 試 験 区

\begin{tabular}{|c|c|c|c|c|}
\hline \multirow{2}{*}{ 因 } & & 水 & 準 & \multirow{2}{*}{ 備 } \\
\hline & 1 & 2 & 3 & \\
\hline 品 & やまかい & やぶきた & かなやみどり & 1. 中䦩型 2 , 直立型 3 , 開張型 \\
\hline 定植時のせん枝の高さ & $15 \mathrm{~cm}$ & $20 \mathrm{~cm}$ & $25 \mathrm{~cm}$ & 定植直後の地表面からの高さ \\
\hline 2 年目のせん枝の高さ & $5 \mathrm{~cm}$ & $10 \mathrm{~cm}$ & $15 \mathrm{~cm}$ & 前年せん枝部からの高さ \\
\hline
\end{tabular}

注） $\mathrm{L}_{27}$ 直交表に割り付子

表3世儿枝処理の時期・方法

\begin{tabular}{|c|c|c|c|c|c|c|c|c|c|}
\hline \multicolumn{3}{|c|}{ 定植加らの年数 } & \multicolumn{3}{|l|}{ 処 } & \multicolumn{2}{|c|}{ 時 期 } & 方 & 法 \\
\hline 1 & 年 & 目 & & 寺の & & \multicolumn{2}{|c|}{$\begin{array}{c}\text { 1976年3 月16 18日 } \\
\text { " }\end{array}$} & \multicolumn{2}{|l|}{ 所定の処理 } \\
\hline 2 & 年 & 目 & 世 & ん & 枝 & \multicolumn{2}{|c|}{ 1977年 5 月18日 } & $"$ & \\
\hline 3 & 年 & 目 & せ & h & 枝 & $\begin{array}{l}\text { やまかい } \\
\text { や゙さた } \\
\text { かやみどり }\end{array}$ & $\begin{array}{l}5 \text { 月 } 4 \text { 日 } \\
5 \text { 月 } 5 \text { 日 } \\
5 \text { 月 } 16 \text { 日 }\end{array}$ & 一般的方法 & \\
\hline
\end{tabular}

表 4 摘採, 整, 世儿枝の時期

\begin{tabular}{|c|c|c|c|c|c|c|c|c|}
\hline \multirow{2}{*}{$\begin{array}{l}\text { 定植から } \\
\Phi \text { 年 数 }\end{array}$} & \multirow{2}{*}{ 品種 } & 一 & 茶 & せ & 枝 & $=$ & 寺 & \multirow{2}{*}{ 整 枝 } \\
\hline & & 方 法 & 時 期 & 処 理 & 時 期 & 方 & 時 期 & \\
\hline 3 年目 & $\begin{array}{l}\text { やまい } \\
\text { やぶきた } \\
\text { かなやみどり }\end{array}$ & 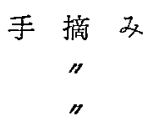 & $\begin{array}{l}5 \text { 月 } 4 \text { 日 } \\
5 \text { 月 } 5 \text { 日 } \\
5 \text { 月 } 16 \text { 日 }\end{array}$ & $\begin{array}{cc}\text { 世 } & \text { ん枝 } \\
\text { (水 } & \text { 平) }\end{array}$ & $\begin{array}{l}5 \text { 月 } 4 \text { 日 } \\
5 \text { 月 } 5 \text { 日 } \\
5 \text { 月 } 16 \text { 日 }\end{array}$ & $\begin{array}{c}\text { はさみ摘み } \\
" \prime \\
" ~\end{array}$ & $\begin{array}{l}6 \text { 月 } 28 \text { 日 } \\
6 \text { 月 } 28 \text { 日 } \\
7 \text { 月 } 3 \text { 日 }\end{array}$ & $\begin{array}{c}\text { 10月 } 4 \text { 日 } \\
n \\
" ~\end{array}$ \\
\hline 4 年目 & $\begin{array}{l}\text { やかい } \\
\text { やぶきた } \\
\text { かなやみどり }\end{array}$ & $\begin{array}{c}\text { はさみ摘み } \\
\text { " } \\
\text { " }\end{array}$ & $\begin{array}{l}5 \text { 月 } 4 \text { 日 } \\
5 \text { 月 } 6 \text { 日 } \\
5 \text { 月 } 11 \text { 日 }\end{array}$ & 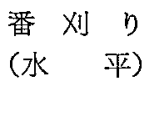 & $\begin{array}{c}5 \text { 月 } 15 \text { 日 } \\
" ~ \\
" ~\end{array}$ & $"$ & $\begin{array}{l}6 \text { 月26日 } \\
6 \text { 月28日 } \\
6 \text { 月28日 }\end{array}$ & $\begin{array}{c}\text { 10月15日 } \\
\text { " } \\
\text { " }\end{array}$ \\
\hline 5 年目 & $\begin{array}{l}\text { やかい } \\
\text { やぶきた } \\
\text { かなやみどり }\end{array}$ & " & $\begin{array}{l}5 \text { 月 } 10 \text { 日 } \\
5 \text { 月12日 } \\
5 \text { 月17日 }\end{array}$ & 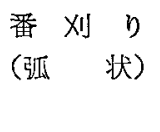 & $\begin{array}{c}5 \text { 月 } 22 \text { 日 } \\
" ~ \\
" ~\end{array}$ & " & $\begin{array}{l}6 \text { 月28日 } \\
7 \text { 月 } 1 \text { 日 } \\
7 \text { 月 } 3 \text { 日 }\end{array}$ & $\begin{array}{c}\text { 10月17日 } \\
\text { " } \\
\text { " }\end{array}$ \\
\hline
\end{tabular}

查を行った。樹形の目安として，株張り/樹高の值を求 めた。

收量については，2年目までは摘採を行わず，3年目 の一番茶を手摘及で行い，3年目の二番茶からは, はさ み摘みとして調ベた。

\section{3 試 騟 結 果}

各調查項目別にみると，次のと拉りである。

\section{1.1 樹}

\section{高}

品種間差についてみると, 分散分折の結果, 表 5 に示 すように，定植当年から 5 年間引き続き有意差が認めら れた。表6に示すよ5に，やぶきたが最正高く，次いて やぬかいでかなやぼりが最低かった。自然仕立て状 態とした定植後 2 年間のせん枝時から秋までの伸びは， 直立型のやぶきた，中間型のやまかい，開张型のかなや
又どりの順に大きかった。はさみ摘み仕立てに変わって ๖，その傾问は同じであった。

定植時のせん枝の高さの影響についてみると，区聞に 有意差が認められ，せん枝位置の高い活5が樹高子高か った。しかし，定植からその年の秋までの伸びでは，15 $\mathrm{cm}$ 区が $19.2 \mathrm{~cm}, 20 \mathrm{~cm}$ 区で $16.4 \mathrm{~cm}, 25 \mathrm{~cm}$ 区が $13.5 \mathrm{~cm}$ となり，世九枝位置の低い汪5が伸びは大きか った。はさみ摘み仕立てに変えた 3 年目以後も樹高につ いて有意差があり，せん枝位嵮の高いほうが樹高は高く なった。

次に，2 年目のせん枝位置の影響についても，区間に 有意差が認められ，せん枝位圆が高い活うが樹高は高く なった。

\section{1.2 株 張 り}

品種間差についてみると, 表 7 に示したよ 5 に，5年 
表 5 臌 高の分 散 分析 (各年と秋隹調査)

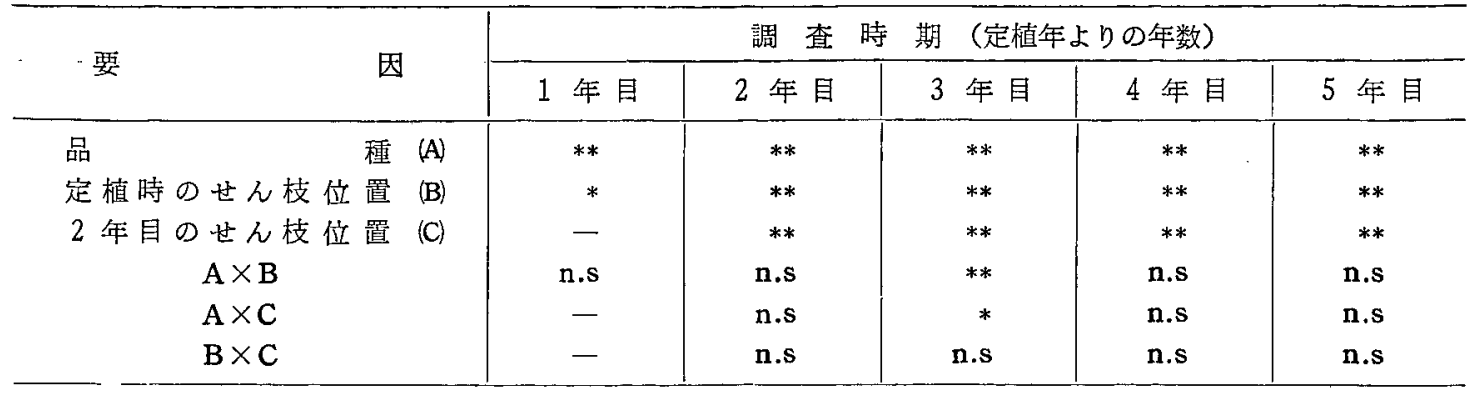

注 * $5 \%$ \%* $1 \%$ で有意であることを示す。

表6 各要因の水準別の樹高

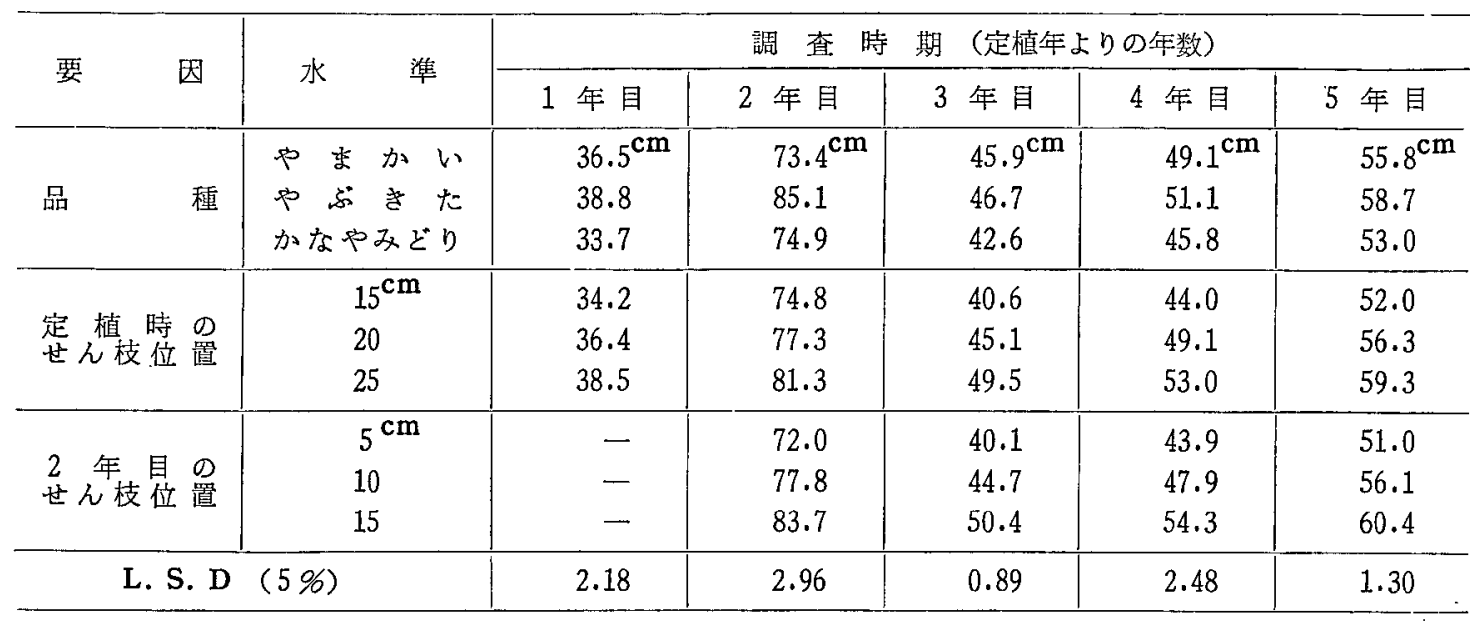

表7 株 張り の 分 散 分 析

\begin{tabular}{|c|c|c|c|c|c|c|c|c|}
\hline \multirow{2}{*}{ 要 } & \multirow[b]{2}{*}{ 因 } & \multicolumn{7}{|c|}{ 調 查 時 期 （定植年よりの年数） } \\
\hline & & 1 年目 & $\begin{array}{l}2 \text { 年自 } \\
\end{array}$ & $\begin{array}{c}2 \text { 年目 } \\
11 \text { 月 }\end{array}$ & $\begin{array}{l}3 \text { 年目 } \\
5 \text { 月 }\end{array}$ & $\begin{array}{c}3 \text { 年目 } \\
11 \text { 月 }\end{array}$ & $\begin{array}{c}4 \text { 年貝 } \\
11 \text { 月 }\end{array}$ & $\begin{array}{c}5 \text { 年貝 } \\
11 \text { 员 }\end{array}$ \\
\hline 品 & 種 (A) & * & * & $* *$ & ** & ** & $* *$ & $* *$ \\
\hline 定植時の世ん枝位 & 置 (B) & n.s & n.s & n.s & $\triangle$ & * & $*$ & * \\
\hline 2 年目の世ん枝位 & 置 (C) & - & * & * & $*$ & $* *$ & $* *$ & ** \\
\hline $\mathrm{A} \times \mathrm{B}$ & & n.s & n.s & n.s & n.s & * & n.s & n.s \\
\hline $\mathrm{A} \times \mathrm{C}$ & & - & n.s & n.s & n.s & n.s & n.s & n.s \\
\hline $\mathrm{B} \times \mathrm{C}$ & & - & n.s & n.s & n.s & n.s & n.s & n.s \\
\hline
\end{tabular}

$\triangle$ は $10 \%, * 15 \%, * * 1 \%$ 有意なるの。

間いずれの年も有意差が認められた。表 8 亿示すよ5に かなやみどり，やまかい，や忍きたの順に大きかった。 2 年目の 5 月のせん枝直後の株張りでは, 品種間の差は それ性ど大きくはなが，その後，3年目の 5 月のせん 枝時までに，かなやみぞりの拡りが特に大きく，他の 2 品種との差が大きくなった。なお， 4 年目以後は品種間 差が縮まる傾向がみられた。

定植時のせん枝の高さによる株張りへの影響について みると，定植から 2 年閒の自然仕立て状態では，有意差 は認められなかった。はさみ摘み仕立てに変壳た 3 年目 以後は，有意差が認められ， 3 年目は $25 \mathrm{~cm}$ 区が最子優
り，次いで，20 cm 区で，15 cm 区が最す劣った。しか し， 4 年目以後は， $25 \mathrm{~cm}$ 区が他区上り大きく，20 cm 区と，15 cm 区の差は認められなかった。

次に， 2 年目の世ん枝の高さの株張りへの影響をみる と, 2 年目から有意差があり， 2 年目の調查では， $5 \mathrm{~cm}$ 区が他の 2 区より小さかったが，3年目以後は $15 \mathrm{~cm}$ 区 が最も大きく，せん枝位圈が低い恬ど株張りは劣った。

\section{1.3 株 張 り/樹高}

品種關についてみると, 分散分析の結果, 表 9 に示す よ5に，いずれの年も有意差か認められた。表10 亿示す よ5に，定植当年の秋から 2 年目の 5 月のせん枝時まで 
表 8 各要因の水準別の株張り

\begin{tabular}{|c|c|c|c|c|c|c|c|c|}
\hline \multirow{2}{*}{ 要 } & \multirow{2}{*}{ 水準 } & \multicolumn{7}{|c|}{ 調 查 時 期 （定植年よりの年数） } \\
\hline & & 1 年目 & 2年目 5 月 & 2年目11月 & 3 年目 5 月 & 3年目11月 & 4年目11月 & 5 年目 11 月 \\
\hline \multirow{3}{*}{ 品 } & や市かい & $25.1^{\mathrm{cm}}$ & $38.0^{\mathrm{cm}}$ & $70.7^{\mathrm{cm}}$ & $71.3^{\mathrm{cm}}$ & $86.6^{\mathrm{cm}}$ & $105.6^{\mathrm{cm}}$ & $120.9^{\mathrm{cm}}$ \\
\hline & やぶきか & 21.8 & 36.0 & 63.0 & 67.3 & 81.2 & 105.8 & 123.5 \\
\hline & かなやみどり & 25.4 & 40.0 & 73.0 & 86.0 & 102.4 & 125.4 & 138.6 \\
\hline \multirow{3}{*}{$\begin{array}{l}\text { 定植時の } \\
\text { せん枝位置 }\end{array}$} & $15^{\mathrm{cm}}$ & 24.1 & 37.7 & 70.7 & 72.3 & 87.5 & 109.5 & 126.6 \\
\hline & 20 & 23.3 & 36.3 & 67.3 & 73.0 & 88.2 & 110.3 & 125.2 \\
\hline & 25 & 25.0 & 40.0 & 70.3 & 79.3 & 94.6 & 116.9 & 131.2 \\
\hline \multirow{3}{*}{$\begin{array}{c}2 \text { 年目の } \\
\text { せん枝位圆 }\end{array}$} & $5^{\mathrm{cm}}$ & - & 36.0 & 65.0 & 69.7 & 84.9 & 107.0 & 122.9 \\
\hline & 10 & - & 39.7 & 71.1 & 76.3 & 90.5 & 110.7 & 126.4 \\
\hline & 15 & - & 39.0 & 70.4 & 78.9 & 95.1 & 118.7 & 133.7 \\
\hline \multicolumn{2}{|c|}{ L. S. D $(5 \%)$} & 2.20 & 3.09 & 4.58 & 5.94 & 4.65 & 4.93 & 4.78 \\
\hline
\end{tabular}

表9 株張り/樹高の分散分析

\begin{tabular}{|c|c|c|c|c|c|c|c|c|c|}
\hline \multirow{2}{*}{ 要 } & \multirow{2}{*}{ 因 } & \multicolumn{8}{|c|}{ 調 查 時 期 （定植年よりの年数） } \\
\hline & & 1 年目 & $\begin{array}{l}2 \\
5\end{array}$ 年貝 & $\begin{array}{c}2 \\
11\end{array}$ 年貝 & $\begin{array}{l}3 \\
5 \\
\end{array}$ & 年自 & $\begin{array}{rr}3 & \text { 年 } \\
-11 & \text { 月 } \\
-1\end{array}$ & $\begin{array}{c}4 \\
11\end{array}$ 年 ${ }^{\text {目 }}$ & $\begin{array}{c}5 \\
11\end{array}$ 年 貝 \\
\hline 品 & 種 (A) & * & $*$ & * & & * & ** & $* *$ & $* *$ \\
\hline 定植時のせん枝位 品 & 置 (B) & n.s & $* *$ & n.s & & $* *$ & ** & ** & $* *$ \\
\hline 2 年目のせん枝位足 & 置 (C) & - & $* *$ & $*$ & & $* *$ & ** & ** & $* *$ \\
\hline $\mathbf{A} \times \mathbf{B}$ & & n.s & n.s & n.s & & n.s & * & n.s & n.s \\
\hline $\mathrm{A} \times \mathrm{C}$ & & - & n.s & n.s & & n.s & * & n.s & n.s \\
\hline $\mathrm{B} \times \mathrm{C}$ & & - & n.s & n.s & & n.s & n.s & n.s & n.s \\
\hline
\end{tabular}

注 $* 5 \%, * * 1 \%$ て有意なるの。

表10 各要因の水準別の株張り/樹高

\begin{tabular}{|c|c|c|c|c|c|c|c|c|}
\hline \multirow{2}{*}{ 要 } & \multirow{2}{*}{ 水 準 } & \multicolumn{7}{|c|}{ 調 查 時 期 （定植年よりの年数） } \\
\hline & & 1 年 目 & 2年目 5 月 & 2年目11月 & 3年目 5 月 & 3年目11月 & 4年目11月 & 5年目11月 \\
\hline \multirow{3}{*}{ 品 } & やまかい & 0.69 & 1.28 & 0.96 & 2.06 & 1.90 & 2.17 & 2.17 \\
\hline & やふきた & 0.56 & 1.23 & 0.74 & 1.89 & 1.75 & 2.08 & 2.11 \\
\hline & かなやみどり & 0.76 & 1.39 & 0.99 & 2.59 & 2.45 & 2.76 & 2.63 \\
\hline \multirow{3}{*}{$\begin{array}{l}\text { 定植時の } \\
\text { せん枝位㯰 }\end{array}$} & $15^{\mathrm{cm}}$ & 0.71 & 1.46 & 0.93 & 2.39 & 2.19 & 2.51 & 2.45 \\
\hline & 20 & 0.64 & 1.29 & 0.88 & 2.12 & 1.98 & 2.26 & 2.24 \\
\hline & 25 & 0.65 & 1.15 & 0.89 & 2.03 & 1.93 & 2.23 & 2.23 \\
\hline \multirow{3}{*}{$\begin{array}{l}2 \text { 年目 9 } \\
\text { せ九枝位㯰 }\end{array}$} & $5^{\mathrm{cm}}$ & - & 1.48 & 0.91 & 2.31 & 2.14 & 2.45 & 2.43 \\
\hline & 10 & - & 1.33 & 0.93 & 2.22 & 2.06 & 2.32 & 2.26 \\
\hline & 15 & - & 1.09 & 0.85 & 2.01 & 1.90 & 2.22 & 2.22 \\
\hline \multicolumn{2}{|c|}{ L. S. D $(5 \%)$} & 0.072 & 0.113 & 0.06 & 0.035 & 0.084 & 0.081 & 0.080 \\
\hline
\end{tabular}

は，かなやみどりが最も大きく，次いでやまかいで， やぶさたが最め小さかった。また，2年目の秋には，か なやみどりとやまかいの差はなくなったが，はさみ摘み 仕立てに変わった 3 年目の秋の調査では， 3 品種の閒に 有意差があり，夰やみどりが最も大きく，次いでやま かいでやぶきたが最す小さかった。 4 年目の秋も同様
の傾向であった。しかし，5年目には，かなやみどりは 他の 2 品種より大きかったが，やまかいとやぶきたの差 は維をり，有意差はなくなった。

定植時のせん枝の高さの影響についてみると，定植当 年と自然仕立て状態であった 2 年目の秋は，せん枝姏理 間に有意差は認められなかった。しかし，その間，5月 
のせん枝直後の調査では，有意差が認められ。定植時の せん枝位置が低い浜万が大きかった。はさみ摘み仕立て に变克てからは，有意差が認められ，世九枝の高さ 15 cm 区が最も大きく，次いで $20 \mathrm{~cm}$ 区で，25 cm 区が最 す小さかった。定植時のせん枝位置を低くした渒らが， 株張り/樹高の值は大きい傾向があった。

2 年目のせん枝の高さの影響についてみると，分散分 析の結果， 2 年目の秋の自然仕立て段階でも差がみら れ，15 cm 区は $10 \mathrm{~cm}$ 区や $5 \mathrm{~cm}$ 区に比較して小さく， $10 \mathrm{~cm}$ 区と $5 \mathrm{~cm}$ 区との間には有意差はみられなかった。 はさみ摘及仕立てに変兄た 3 年目以後は，世九枝処理間 に有意差が認められ， $5 \mathrm{~cm}$ 区が最も大きく，次いで 10 $\mathrm{cm}$ 区で, $15 \mathrm{~cm}$ 区が最も小さかった。

\section{1 .4 分 枝 数}

品種についてみると，定植してから 2 力後の調査で は，表11飞示すよ5に，品種間に有意差は櫬められなか ったが，定植当年の秋には，品種間隹有意差が認められ， やまかいが他の 2 品種より多く，やぶきたとかなやみど りの差はみられなかった。 2 年目の秋の調查です品種間 に差がみられ，やぶきたが他の 2 品種より少なく，やま
かいとかなやみどりの差はなかった。3 年目の秋の枝数 を摘採面について調查した結果で，品種間隹有意差が 認められ，かなやみどりが最も多く，次いでやまかいで やぶきたは最も少なかった。

定植時のせん枝の高されよる影響をみると，定植して から 2 力月後の調查では，有意差は認められなかったが， 定植年の秋の分枝数では有意差が認められ，せん枝の高 さの高い活5が多かった。3 年目の秋の枝数も，5\%水 準では有意差はなかったが, 10\%水準では有意差があり， せん枝の位置の高いほうが多かった。

2 年目のせん枝の高さによる影響をみると， 2 年目の 秋の調查で，品種と 2 年目のせ九枝の高さの間に，交互 作用がみられた。即ち，かなやみどりとやぶきたでは 10 $\mathrm{cm}$ 区が多かったが，やまかいでははっきりした傾向は みられなかった。

\section{1.5 幹 \\ 径}

定植当年の秋と 2 年目の秋仪調查したが，品種間や定 植時のせん枝位置および 2 年目のせん枝位置による美は みられなかった。

3. 1.6 世 ん枝量

表11 分枝数の分散分析

\begin{tabular}{|c|c|c|c|c|c|}
\hline 西 & \multirow{2}{*}{ 因 } & \multicolumn{4}{|c|}{ 調 查 時 期 （定植年よりの年数） } \\
\hline 安 & & 定植 2 ヶ月後 & 1 年目 11 月 & 2 年目 11 月 & 3 年目 11 月 \\
\hline 品 & (A) & n.s & ** & * & * \\
\hline 定植時の世ん枝位 & (B) & n.s & * & n.s & n.s \\
\hline 2 年目の世ん枝位 & (C) & - & n.s & n.s & n.s \\
\hline $\mathrm{A} \times \mathbf{B}$ & & n.s & $\mathrm{n} . \mathrm{s}$ & $\mathrm{n} . \mathrm{s}$ & n.s \\
\hline $\mathrm{A} \times \mathrm{C}$ & & - & n.s & * & n.s \\
\hline $\mathrm{B} \times \mathrm{C}$ & & - & n.s & n.s & n.s \\
\hline
\end{tabular}

表12 各要因の水準別分枝数（本/株）

\begin{tabular}{|c|c|c|c|c|c|}
\hline \multirow{2}{*}{ 要 } & \multirow{2}{*}{ 水 準 } & \multicolumn{4}{|c|}{ 調 查 時 期 （定植年よりの年数） } \\
\hline & & 定植 2 ヶ月後 & 1 年目 11 月 & 2 年目 11 月 & 3 年目 11 月 \\
\hline 品 & 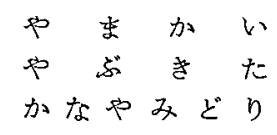 & $\begin{array}{l}3.0 \\
2.7 \\
2.7\end{array}$ & $\begin{array}{l}9.5 \\
8.3 \\
8.1\end{array}$ & $\begin{array}{l}16.5 \\
15.0 \\
16.7\end{array}$ & $\begin{array}{l}23.7 \\
21.4 \\
30.6\end{array}$ \\
\hline $\begin{array}{l}\text { 定植時 } \\
\text { 世枝位置 }\end{array}$ & $\begin{array}{l}15^{\mathrm{cm}} \\
20 \\
25\end{array}$ & n.s & $\begin{array}{r}6.8 \\
8.3 \\
10.7\end{array}$ & n.s & $\begin{array}{l}(22.3) \\
(25.1) \\
(28.4)\end{array}$ \\
\hline $\begin{array}{l}2 \\
\text { せ九年枝位置 }\end{array}$ & $\begin{array}{l}5^{\mathrm{cm}} \\
10 \\
15\end{array}$ & $\begin{array}{l}- \\
- \\
-\end{array}$ & $\begin{array}{l}- \\
- \\
-\end{array}$ & n.s & n.s \\
\hline & 5. $D(5 \%)$ & & 0.78 & 1.54 & \\
\hline
\end{tabular}

注 1) 3 年目の秋は $20 \mathrm{~cm} \times 20 \mathrm{~cm}$ の枠内を調査

2)（）は10\%で有意なるのを参考のため記した。 
品種閔についてみると， 2 年目の一番茶後に，世九枝 を行ったときのせん枝量について，分散分析を行った結 果，表13に示したよ5に有意差がみられ，表14に示すよ 5 に，やぶきたが他の 2 品種より多く，やまかいとかな やみどりでは有意差は認められなかった。3 年目の一番 茶後のせん枝量では，品種間に有意差は認められなかっ た。

定植時のせん枝の高さの影響についてみると， 2 年目

表13世ん枝量の分散分析

\begin{tabular}{|c|c|c|c|}
\hline \multirow{2}{*}{ 要 } & \multicolumn{3}{|c|}{$\begin{array}{c}\text { 調 查 時 期 } \\
\text { (定植年よりの年数) }\end{array}$} \\
\hline & 2 年目 & 3 & 年目 \\
\hline 種 (A) & $* *$ & & n.s \\
\hline 定植時の世九枝位置 (B) & $*$ & & * \\
\hline 2 年目のせん枝位置 (C) & $* *$ & & n.s \\
\hline $\mathrm{A} \times \mathrm{B}$ & n.s & & n.s \\
\hline $\mathrm{A} \times \mathrm{C}$ & n.s & & n.s \\
\hline $\mathrm{B} \times \mathrm{C}$ & n.s & & n.s \\
\hline
\end{tabular}

注） *5\%,**1\%で有意であることを示す。

表14 各要因の水準別せん枝量

\begin{tabular}{|c|c|c|c|}
\hline \multirow{2}{*}{ 要 } & \multirow{2}{*}{ 水 準 } & \multicolumn{2}{|c|}{$\begin{array}{c}\text { 調 查 時 期 } \\
\text { (定植年よりの年数) }\end{array}$} \\
\hline & & 2 年目 & 3 年目 \\
\hline \multirow{3}{*}{ 品 } & 中㭗か & $255.9^{\mathrm{g}}$ & $\mathrm{g}$ \\
\hline & やぶきた & 336.9 & \\
\hline & かなやみどり & 245.3 & \\
\hline \multirow{3}{*}{$\begin{array}{l}\text { 定植時 の } \\
\text { せん枝位固 }\end{array}$} & $15^{\mathrm{cm}}$ & 342.2 & 1596 \\
\hline & 20 & 278.4 & 1133 \\
\hline & 25 & 217.4 & 1302 \\
\hline \multirow{3}{*}{$\begin{array}{l}2 \text { 年目 } \\
\text { せん枝位置 }\end{array}$} & $5^{\mathrm{cm}}$ & 456.4 & \\
\hline & 10 & 271.0 & \\
\hline & 15 & 110.7 & \\
\hline \multicolumn{2}{|c|}{ L. S. D } & 76.29 & 281.2 \\
\hline
\end{tabular}

注）10株当たりのせん枝量で示した。
の一番茶後の調查て，有意差が認められ，15 cm 区は $25 \mathrm{~cm}$ 区より多かった。なお，統計的には有意でなかっ ためのの，せん枝位置が低いほど，せ九枝量は多かった。 3 年目の一番茶後に，世ん枝を行ったときのせん枝量で 有意差が認められ，15 cm 区か： $20 \mathrm{~cm}$ 区や $25 \mathrm{~cm}$ 区 より多く，20 cm 区と $25 \mathrm{~cm}$ 区の間には有意差は認め られなかった。

2 年目のせん枝の高さの影響をみると，2 年目の一番 茶後の世ん枝量について分散分析を行った結果，有意差 が認められ，せん枝の高さが低い泜ど，せん枝量は多か った。3 年目の一番茶後のせん枝量では， 2 年目のせん 枝の高さによる差は認められなかった。

\section{2 樹高, 株張り, 株張り/樹高の間の相関}

樹高と株張り，樹高と株張り/樹高，株張りと株張り/ 樹㣎の各々の相関を求めて表 15に示した。

\section{2. 1 樹高亡株 張り}

なかには，相関係数の小さいものもあるが，全体とし ては正の相関が高かった。

\section{2.2 樹高と株張り/樹高}

全体に真の相関が䓪かった。

\section{2. 3 株張りと株張り/樹高}

はっきりした傾向はみられなかった。

\section{3 収量および収罟構成要素}

収量括よび収量棈成要素についての分散分析の結果を 表16に示した。また，分散分析の結果，有意であったも のの各要素の水準別の值を表 17 に示した。

\section{3.1 定植から 3 年目の調查}

一番茶の $10 \mathrm{a}$ 当たり収量では, 品種間には有意差が認 められたが，定植時あるいは 2 年目のせん枝の高さによ る差は認められなかった。品種では，かなやみどりが他 の2品種より多く，や焉かいやら゙きたの差は性とんど なかった。二番茶は，はさみ摘みを行ったが，一番茶と， ほ滨同じ傾向であった。

一〜二番茶の合計収量すかなやみどりが他の 2 品種よ り多く，やぶきたやまかいでは匡とんど差はなかっ た。

表15 樹高，株張 り，张 り/樹高の間の相関

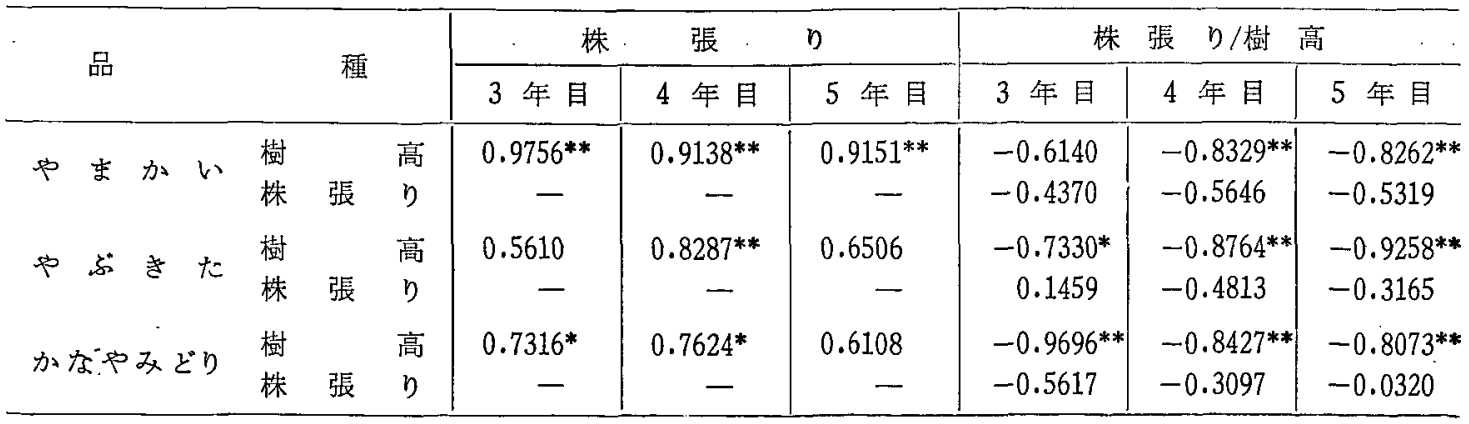

注） $* 5 \%, * * 1 \%$ 有意なるのを示す。 
第 56 号 (1 $\left.\begin{array}{llll}1 & 9 & 8 & 2\end{array}\right)$

表16収量拉よび収量構成の分散分折

\begin{tabular}{|c|c|c|c|c|c|c|c|c|c|c|c|c|}
\hline \multirow{3}{*}{ 要 項目 } & \multicolumn{7}{|c|}{-} & \multicolumn{3}{|c|}{ 茶 } & \multirow[b]{2}{*}{ 芽 } & \multirow[b]{2}{*}{ 重 } \\
\hline & \multicolumn{3}{|c|}{$10 \mathrm{a}$ 当たり収量 } & \multicolumn{3}{|c|}{ 染摘 み収量 } & 新 & 芽 & 数 & 百 & & \\
\hline & 3 & 4 & 5 & 3 & 4 & 5 & 3 & 4 & 5 & 3 & 4 & 5 \\
\hline 種 (A) & $* *$ & * & $* *$ & - - & $* *$ & $* *$ & - & ** & $*$ & - & $* *$ & n.s \\
\hline 定植時のせん枝位置 (B) & n.s & $\mathrm{n} . \mathrm{s}$ & n.s & - & n.s & n.s & - & $\mathrm{n} . \mathrm{s}$ & n.s & - & * & n.s \\
\hline 2 年目の世ん枝位置 (C) & n.s & $* *$ & * & - & n.s & n.s & - & n.s & n.s & - & $*$ & n.s \\
\hline $\mathrm{A} \times \mathrm{B}$ & n.s & n.s & $\mathrm{n} . \mathrm{s}$ & - & $\mathrm{n} . \mathrm{s}$ & n.s & - & $\mathrm{n} . \mathrm{s}$ & n.s & 一 & n.s & n.s \\
\hline $\mathrm{A} \times \mathrm{C}$ & n.s & n.s & n.s & - & $\mathrm{n} . \mathrm{s}$ & n.s & - & n.s & n.s & - & n.s & $\mathrm{n} . \mathrm{s}$ \\
\hline $\mathrm{B} \times \mathrm{C}$ & n.s & $\mathrm{n} . \mathrm{s}$ & $\mathrm{n} . \mathrm{s}$ & - & n.s. & $\mathrm{n} . \mathrm{s}$ & - & n.s & n.s & - & $\mathrm{n} . \mathrm{s}$ & n.s \\
\hline 茶 期 & \multicolumn{5}{|c|}{$=$} & \multicolumn{2}{|c|}{ 番 } & \multicolumn{3}{|c|}{ 茶 } & & \\
\hline & \multicolumn{3}{|c|}{$10 \mathrm{a}$ 当たり汉量 } & \multicolumn{3}{|c|}{ 染摘 又収量 } & 新 & 芽 & 数 & 百 & 芽 & 重 \\
\hline 因 年 次 & 3 & 4 & 5 & 3 & 4 & 5 & 3 & 4 & 5 & 3 & 4 & 5 \\
\hline 種 (A) & $* *$ & * & * & - & $* *$ & * & - & $*$ & * & - & * & $* *$ \\
\hline 定植時のせん枝位置 (B) & n.s & n.s & $\mathrm{n} . \mathrm{s}$ & - & $\mathrm{n}, \mathrm{s}$ & $\mathrm{n} . \mathrm{s}$ & - & n.s & n.s & - & n.s & n.s \\
\hline 2 年目のせん枝位置 (C) & $\mathrm{n} . \mathrm{s}$ & $* *$ & $\mathrm{n} . \mathrm{s}$ & - & $\mathrm{n} . \mathrm{s}$ & $\mathrm{n} . \mathrm{s}$ & - & n.s & n.s & - & n.s & $* *$ \\
\hline $\mathrm{A} \times \mathrm{B}$ & n.s & $\mathrm{n} . \mathrm{s}$ & $\mathrm{n} . \mathrm{s}$ & - & n.s & $\mathrm{n} . \mathrm{s}$ & - & $\mathrm{n} . \mathrm{s}$ & n.s & - & n.s & n.s \\
\hline $\mathrm{A} \times \mathrm{B}$ & n.s & $\mathrm{n} . \mathrm{s}$ & $\mathrm{n} . \mathrm{s}$ & - & n.s & $\mathrm{n} . \mathrm{s}$ & - & $\mathrm{n} . \mathrm{s}$ & n.s & - & n.s & n.s \\
\hline $\mathrm{B} \times \mathrm{C}$ & n.s & $\mathrm{n} . \mathrm{s}$ & n.s & - & n.s & n.s & - & $\mathrm{n} . \mathrm{s}$ & n.s & - & $\mathrm{n} . \mathrm{s}$ & n.s \\
\hline 項 目 & \multicolumn{3}{|c|}{ 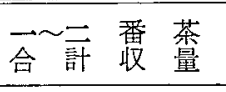 } & \multicolumn{3}{|c|}{$10 \mathrm{a}$ 当たり秋整枝量 } & & & & & & \\
\hline 因年 次 & 3 & 4 & 5 & 3 & 4 & 5 & & & & & & \\
\hline 種 (A) & ** & * & * & ** & $* *$ & $\mathrm{n} . \mathrm{s}$ & & & & & & \\
\hline 定植時の世ん枝位置 (B) & n.s & n.s & $\mathrm{n} . \mathrm{s}$ & n.s & n.s & $\mathrm{n} . \mathrm{s}$ & & & & & & \\
\hline 2 年目の也ん枝位置 (C) & n.s & $* *$ & n.s & $* *$ & n.s & n.s & & & & & & \\
\hline $\mathrm{A} \times \mathrm{B}$ & n.s & n.s & n.s & $\mathrm{n} . \mathrm{s}$ & n.s & $\mathrm{n} . \mathrm{s}$ & & & & & & \\
\hline $\mathrm{A} \times \mathrm{C}$ & n.s & $\mathrm{n} . \mathrm{s}$ & $\mathrm{n} . \mathrm{s}$ & $\mathrm{n} . \mathrm{s}$ & n.s & $*$ & & & & & & \\
\hline $\mathrm{B} \times \mathrm{C}$ & n.s & $\mathrm{n} . \mathrm{s}$ & $\mathrm{n} . \mathrm{s}$ & $\mathrm{n} . \mathrm{s}$ & $* *$ & n.s & & & & & & \\
\hline
\end{tabular}

注） $* 5 \%, * * 1 \%$ 有意なるのを示す。

秋整枝量では，品種間および 2 年目のせん枝の高さの

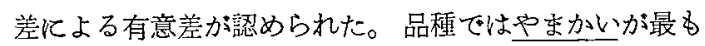
多く，次いでやぶきたで，かなやみどりが最も少なかっ た。2年目のせん枝位固では，世九枝の高いほうが秋整 枝量は多かった。

\section{3.2 定植から 4 年目の調査}

一番茶の $10 \mathrm{a}$ 当たり収量をみると, 品種間㧍よび2 年目のせん枝の高さの問に有意差が認められた。品種で 㳊かなやみどりが最も多収で，次いでやぶきたで，やま かいが最も少収であった。2 年目のせん枝の高さでは， $15 \mathrm{~cm}$ 区が $5 \mathrm{~cm}$ 区上り収量が多かった。 $5 \mathrm{~cm}$ 区と $10 \mathrm{~cm}$ 区, $10 \mathrm{~cm}$ 区之 $15 \mathrm{~cm}$ 区の間では有意差はなか ったが，せん枝位置が高い活らが，収量は多い傾向がみ られた。

一番茶の枠摘み収量では, 品種間に有意差が認められ たが，定植時あるいは2 年目のせん枝の高さの間では有 意差は認められなかった。品種では，10a 当たり収量々
同栐に，かなやみどりが最も多く，次いでやぶさたで， やをかいが最も少なかった。2 年目のせん枝の高さの間 に有意差は認められなかったが，せ九枝の高さが高い非 万が枠摘み収量が多い傾向がみられた。

一番茶の新芽数では，品種間億有意がみら，かな やみどりが最も多く，次いでや占さたで，や本かいが最 す少なかった。定植時あるいは 2 年目の世儿枝の高さの 間には有意差は認められなかった。

一番茶の百芽重では, 品種間, 定植時および 2 年目の せん枝の高さの間で有意差か認められた。品種では，か なやみどりが他の 2 品種より軽く，やぶきたとやまかい の差はほとんどなかった。定植時のせん枝位置では，25 $\mathrm{cm}$ 区は $20 \mathrm{~cm}$ 区や1 $5 \mathrm{~cm}$ 区より重かった。2 年目の せん枝位置でる，せん枝位置が高い棌ど，百芽重は重か った。

二番茶の $10 \mathrm{a}$ 当たり収量についてみると，品種間拉 よび 2 年目のせん枝の高さの間に有意差が認められた。 
茶業研究報告

表17各要因の水準別収量および収量構成

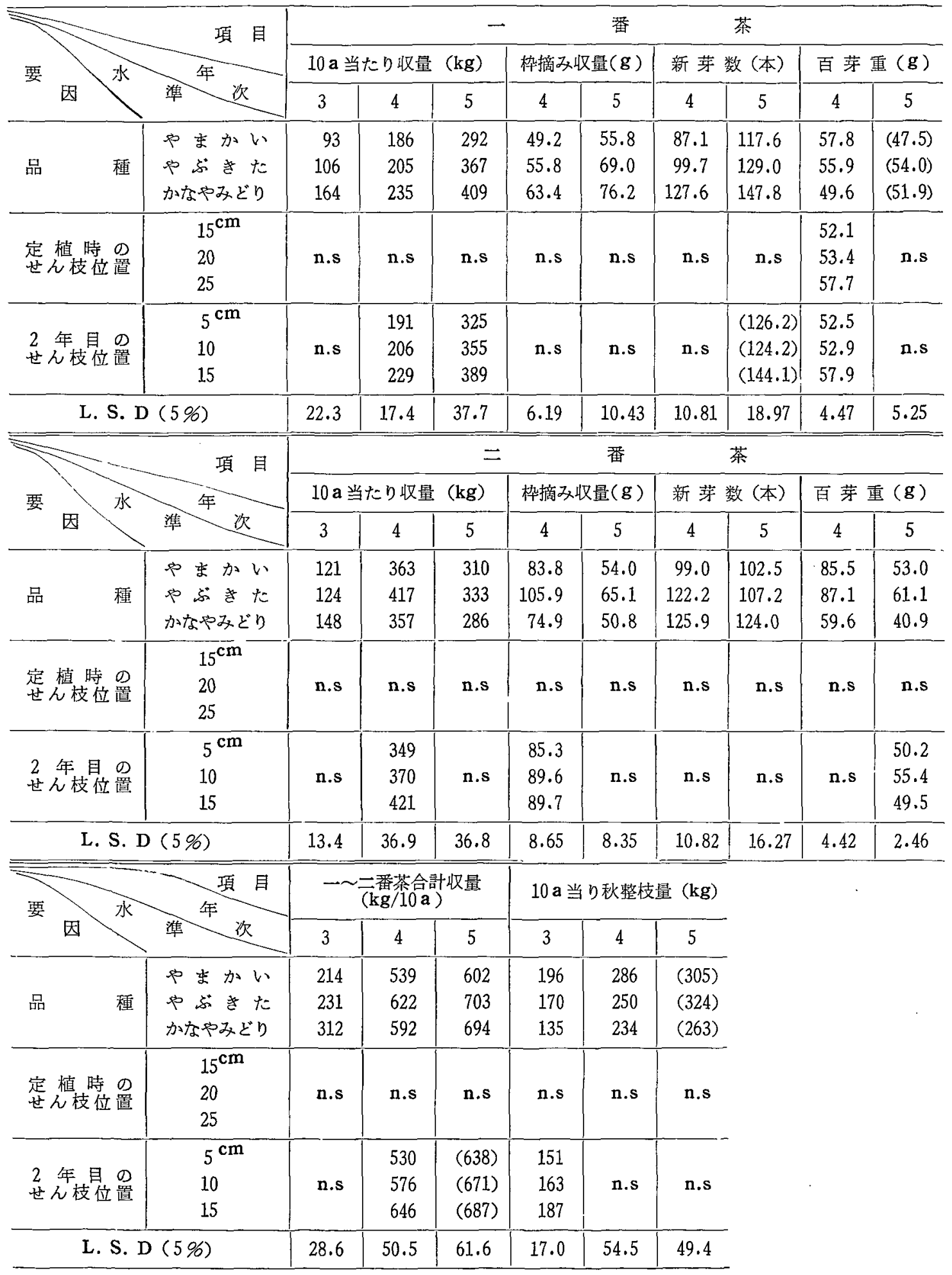

（）は 10\%で有意のものである。 
品種では，やぶきたが他の2 品種より多く，やまかいと かなやみどりの差少なかった。前年の㑯向と変ったの は，この年から，かなやみどりの二番茶芽の生育が悪く なったためである。2 年目のせん枝の高さでは， $15 \mathrm{~cm}$ 区が $10 \mathrm{~cm}$ 区や $5 \mathrm{~cm}$ 区より多収であった。統計的には 有意でないるのの，せん枝の高さの高い活らが，収量は 多い傾向がみられた。

二番茶の枠摘み収量についてみると, 品種間に有意差 が認められ，やぶきたが最も多く，次いて゚やまかいで， かなやみどりが最も少なかった。定植時あるいは 2 年目 のせん枝の高さの間では有意差は認められなかった。

二番茶の 新芽数では，品種問に有意差が認められ， やまかいが他の 2 品種より少なく，やぶきたとかなやみ どりの差はほとんどなかった。定植時あるいは2 年目の せん枝の高さの間には有意差は認められなかった。

二番茶の百芽重では，やぶきたとやまかいの差はほと んどなかったが，かなやみどりは他の2品種より少なか った。定植特あるいは 2 年目のせん枝の高さの間に有意 差は認められなかった。

一〜二番茶の合計収量では，品種間および 2 年目の世 几枝の高さの間で有意差が認められた。品種ではやぶさ たが最も多く，次いでかなやみどりで，やまかいが最す 少なかった。2 年目の世ん枝の高さては，15 cm 区が 5 cm 区より多く，統計的には有意でないるのの，世ん枝 の高さが高い至らが収量は多い傾向がみられた。

秋の整枝量では，品種間に有意差が認められ，やまか 汃最も多く，次いでやら゙きたて，かなやみどりが最る 少なかった。定植時のせん枝位圈と 2 年目のせん枝位萱 との間には交互作用がみられた。定植時のせん枝の高さ が $15 \mathrm{~cm}$ と $20 \mathrm{~cm}$ の場合ば 2 年目のせん枝の高さ 15 $\mathrm{cm}$ 区の秋整枝量が多く，定植時のせん枝の高さが 25 $\mathrm{cm}$ の場合は 2 年目のせん枝の高さの低い $5 \mathrm{~cm}$ 区の整 枝量が多かった。

\section{3.3 定植から5 年目の調查}

一番茶の $10 \mathrm{a}$ 当たり収量では，品種間および 2 年目 のせん枝位置で有意差が喼められた。品種では，がなや みどりが最多収で，次いでやぶきたでややまかいは最 あ分収であった。2 年目の世ん枝の高さについてみると， $15 \mathrm{~cm}$ 区は $5 \mathrm{~cm}$ 区や $10 \mathrm{~cm}$ 区より多収となった。 5 $\mathrm{cm}$ 区と $10 \mathrm{~cm}$ 区の間には有意差はないものの，世ん枝 位置の高い㴗5が、収量は多い傾向がみられた。

一番茶の枠摘み収量についてみると，品種間に有意差 がみられ，㔔やみどりが最も多く，次いでやぶきた で,や杂加は最も少なかった。定植時あるいは2年目 のせん枝位置の閒には有意差は認められなかった。

一番茶の新芽数では，品種間に有意差がみられ，かな やみどりが他の 2 品種より多く，やぶさたとやまかいの 間には有意差はみられなかった。定植時あるいは2 年目
のせん枝位置の間では有意差はみられなかった。一番茶 の百芽重では，品種間や定植時あるいは 2 年目のせん枝 位置の間では有意差は認められなかっった。

二番茶の $10 \mathrm{a}$ 当たり収量では，品種間に有意差が認 められ，やぶきたが最鸟多収で，次いでやまかいで， かなやみどりが最る少收であった。定植時あるいは 2 年 目のせん枝位置の間には有意差は認められなかった。

二番茶の枠摘み収量では，品種間に有意差が認めら れ，やぶきたが他の 2 品種より多く，やまかいとかなや みどりの差はなかった。定植時あるいは2 年目のせん枝 位置の間には有意差は認められなかった。

二番茶の新芽数では，品秷間に有意差が認められ，か なやみどりが他の 2 品種より多く，やまかいいとやぶた の間には有意差は認められなかった。定植時あるいは2 年目のせん枝位置の間には有意差は認められなかった。

二番茶の百芽重ては，品種間や定植時あるいは 2 年目 のせん枝位置の間に有意差は認められなかった。

一〜三蓞茶の合計収量せは，品種閒に有意差が認めら れ，やまかいは他の2 品種より低収であった。やぶきた とかなやみどりでは差はなかった。定植時や2 年目の世 ん枝位置の間では有意差は認められなかった。

$10 \mathrm{a}$ 当たりの秋整枝量で，品種と 2 年目のせん枝位 䈯との閏に交互作用が双られ，や要かいでは $5 \mathrm{~cm}$ 区が 多く，やぶきたでは $10 \mathrm{~cm}$ 区，かなやみどりでは $15 \mathrm{~cm}$ 区が多かった。

\section{4 樹高, 株張り, 株張り/樹高と収量との関係}

樹高之収量, 株張りと収量, 株張り/樹高と収量のそ れぞれの相関係数を表 18 に示した。

樹高と収量の間では，品種や年次により多少の振れは あるが，樹高の高い活うか収量は多い傾向がある。これ は株張りとの関係があるるのと思われる。

株張りと収量の間でば 自然仕立てからはさみ摘み仕 立てに变えた 3 年目を除けば，株張りと収量との間には 高い正の相問がある。早期に成園化するには，株張りを 早く掋げる必要があることを示している。

株張り/樹高と収量の間では，はっきりした傾向はみら れなかった。

\section{4 考察}

幼木園の仕立ては，品種や苗木の大きさあるいは栽植 方法などにより変わってくる。

仕立てに当たっては, せ九枝時期や程度, 自然仕立て からはさみ摘み仕立てに変党る年次など多くの要因が考 えられるが，この試験では，直立型のやぶきた，中間型 のやまかい，開張型のかなやみどりを用いて，定植時の せん枝の高さと 2 年目のせん枝位置（定植時のせん枝位 置からの高さ）を变劣て，早期に成木園にするための仕 立ての条件を検討した。 
表18樹高, 株張り, 株張り/樹高と収量の相関

\begin{tabular}{|c|c|c|c|c|c|c|c|c|c|c|}
\hline \multirow{2}{*}{ 品 } & \multirow{2}{*}{ 種 } & \multicolumn{3}{|c|}{ 一 番 茶収量 } & \multicolumn{3}{|c|}{ 二番 茶収量 } & \multicolumn{3}{|c|}{ 計 } \\
\hline & & 3 年目 & 4 年目 & 5 年目 & 3 年目 & 4 年目 & 5 年目 & 3 年目 & 4 年目 & 5 年目 \\
\hline \multirow{3}{*}{ やまかい } & & -0.1975 & 0.8738 & 0.7876 & 0.0946 & 0.5920 & -0.3449 & 0.1058 & 0.8819 & $0.709^{*}$ \\
\hline & 株 張 り & -0.1206 & $0.9001^{* *}$ & $0.9334^{* *}$ & 0.1528 & 0.6634 & -0.5512 & -0.0268 & $0.855^{* *}$ & $0.7481^{*}$ \\
\hline & 株張り/樹高 & 0.2405 & -0.6339 & -0.3654 & 0.1298 & -0.2047 & -0.0469 & 0.2270 & -0.6926 & -0.4644 \\
\hline \multirow{3}{*}{ やぶきた } & & 0.3139 & 0.4010 & $0.7443^{*}$ & -0.0957 & 0.8240 & - & 0.2851 & $0.7696^{*}$ & - \\
\hline & 株 張 り & 0.8602 & 0.6548 & 0.5367 & 0.2977 & $0.81 \stackrel{* *}{9}$ & - & $0.7750^{*}$ & $0.8150^{* *}$ & - \\
\hline & 株張り/樹嵩 & 0.3151 & -0.0959 & -0.6639 & 0.3297 & -0.5513 & - & 0.2680 & -0.4613 & - \\
\hline \multirow{3}{*}{$\begin{array}{l}\text { かな } \\
\text { みどり }\end{array}$} & 樹 & -0.2321 & 0.8264 & 0.7436 & 0.1190 & $0.747^{*}$ & -0.1498 & -0.3038 & $0.7977^{*}$ & 0.5427 \\
\hline & 株 張 & 0.2130 & $0.7540^{*}$ & 0.8764 & 0.3441 & $0.7566^{*}$ & 0.1594 & 0.5557 & $0.7740^{*}$ & $0.7766^{*}$ \\
\hline & 株張り/樹高 & 0.3096 & -0.6478 & -0.3065 & -0.0760 & -0.5233 & 0.3117 & 0.3983 & -0.5865 & -0.1217 \\
\hline
\end{tabular}

注） $* 5 \%, * * 1 \%$ 有意なるのを示す。

$3 つ の$ 要因について, 直交表 $\mathrm{L}_{27}$ K割り付けて試験を 行ったが，品種と定植時あるいは 2 年目のせん枝位置と の間の交互作用は任とんどみられなかった。せん枝によ る影響は，各々の品種に同様であることを示している。 そらしたことをると考察する。

まず，世九枝処理によって分枝数がどのように変わる かについてみると，定植年の秋の杪当たり竹枝数は，定 植時のせん技位置の高い经らが多かった。しかし，その 後の調査では有意差が諗められなかった。また，はさみ 摘又に变わってからの新芽数でも，定植時や 2 年目の女 ん枝の高さの間隹有意差は認められなかった。

次に，収量についてみると，いずれの品種子株張りと の相関が高く，株張りの大きい活らが収量は多い傾向が みられる。定植時あるいは 2 年目のせん枝の高さでは， 高くせん枝した洼うが，収量は多、傾向がある。これは 高くせん枝した活らが，株張りが大きいためと思われ る。

大苗移植や複条植えの場合は，株張りを拡げることは 容易であるが， 2 年生苗で単条植えの場合は，株張りを 拡げていくことが前者に比べて難しいので，早期に株張 りを拡げていくことが，早期成園化への一つの条件であ ると思われる。

株張りと樹高との相関が高いのは, 田中らの報告と同 様であった。定植時のせん枝位置や 2 年目のせ儿枝位置 を高くすることによって，いずれの品種も樹高が高くな ると同時侏張りる大きくなる。しかし，その伸び方に 品種間差がある。やぶきたは樹高の伸ざは非常に良いが, 株張りの拡がりは遅い。これはせん枝量が多いことから もらかがる。かなやみどりは，逆江澍高はそ机潘ど伸 びないが株張りは大きくなり易い。特に 3 年目までの
株張りの増加が大さい。

樹高とともに株張りも十分でないと多収が得られな い。たとえば，樹高 $60 \mathrm{~cm}$ のと，株張りは $150 \mathrm{~cm}$ 以 上必要である。そこで，樹形の目安としての株張り/樹高 の值を求めてみた。成木園に達したとき 2.5 以上は必要 であり，この值が小さいほど縱長となる。縦長になると らねの部位別の芽揃いが悪くなり，多収は得られない。 また，二人用の摘採機などには適さない。

定植後 5 年目末での株張り/樹高の值をみると, 品種 間に差が双られ，亘立型のやぶきたは小さく，開張型の かなやみどりは大きな值を示す。中間型のやまかいはや ぶさたとかなやみどりの間にあるが，やぶされ近い值 を示す。

自然仕立ての間は，この値は小さく，はさ双摘み仕立 てに変点ると急激に大きくなるのは当然であるが，2 年 目と 3 年目の 5 月のせん枝直後の值でみると，: 2 年目か ら 3 年目に急激化増加している。更に，3年目から 4 年 目にかけても，かなり大きくなるが，4 年目から 5 年目 の増加はわずかである。

せえ枝位置との関係をみると，定植時や 2 年目のせん 枝位置が高いと，株張り/樹高の値は小さくなる。

澍姿との関倸でみると，やぶきたのような直站型の品 種は，せん枝位置を高めると，株張蛙大きくるが， 樹高の伸びす非常に大きいので，株張り/樹高の值は小 さくなる。例点ば，定植時のせん枝の高さを $25 \mathrm{~cm} ， 2$ 年目のせ九枝の高さを $15 \mathrm{~cm}$ とすると，株張り/樹高の 値は 1.6(かなやみどりは 2.0) と非常に小さくなった。一 方，かなやみどりのような開張型の品種は，定植時や2 年目のせん枝位置を高くしてる，樹高の伸びはやぶきた より小さく，株張りは非常に大きくなる。株張り/樹高 
第 56 号 ( 19982$)$

表19年次別の樹高, 株張り, 株張り/樹高の目安

\begin{tabular}{|c|c|c|c|c|c|c|c|c|}
\hline \multirow{2}{*}{ 年 } & \multirow{2}{*}{ 次 } & \multicolumn{3}{|c|}{ や ぶきた（值立型） } & \multicolumn{3}{|c|}{ かなやみどり（開張型） } & \\
\hline & & 樹 高 & 株 張 り & 株張り/樹高 & 樹高 & 株 張 り & 株張り/樹高 & \\
\hline 1 & 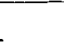 & $15^{\mathrm{cm}}$ & $\mathrm{cm}$ & & $20^{\mathrm{cm}}$ & $\mathrm{cm}$ & & 一滛苶後の \\
\hline 2 & 2 & 25 & 38 & 1.5 & 35 & 46 & 1.3 & 世九枝徝後 \\
\hline 1 & 3 & 35 & 77 & 2.2 & 45 & 113 & 2.5 & \\
\hline s & 4 & 45 & 108 & 2.4 & 50 & 130 & 2.6 & 秋整枝後 \\
\hline 5 & 5 & 55 & 138 & 2.5 & 55 & 150 & 2.7 & \\
\hline ( & 6 & 60 & 150 & 2.5 & & & & \\
\hline
\end{tabular}

の值は，定植時や 2 年目のせん枝位置を高めることによ って低下はするが，比較的大きな值を維持できる。

こらしたことから，やぶきたのような直立型の品種は， 株張り/樹高の值を，でるたけ大さ保ちつつ，林張り の增大を図ることが必要である。定植時のせん枝の高さ を $15 \sim 20 \mathrm{~cm}$ とし， 2 年目のせん枝位置を，定植時の せん枝位置より $10 \mathrm{~cm}$ 程度にするのが適当と思われる。

かなやみどりのような開張型の品種では，株張り/樹高

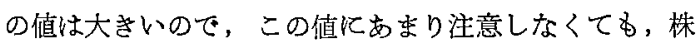
張りの应大を図ればよいと思われる。こうした品種では 定植時のせん枝の高さを $20 \sim 25 \mathrm{~cm}$ とし， 2 年目のせん 枝位置を定植時の世ん枝位置から 10〜15 cm とするのが 適していると思われる。これより高くせん枝すると，開 張型品種とい点ども，株張り/樹高の値が小さくなり過 ぎて，5〜7年で成榬俚達したとき，株張りが十分で ない危険がある。

中間型の品種については，品種によって，より開張型 に近いるのから，直立型に近いるのがあると思われるの でそこした特性により変えるべきすのと思われる。 やまかいについては，定植時のせん枝位置を $20 \mathrm{~cm}$ 程度 とし， 2 年目のせん枝位置は，定植時のせん枝位置から $10 \mathrm{~cm}$ 程度上げて行万のが適当と思われる。

これらをもとに，定植からの年次別の樹高，株張り， 株張り/樹高の值を表 19 亿示してみた。なお, 取り扱っ た品種も少なく, 更に多くの品種について検討する必要 がある。

\section{5 摘要}

1 1976年3月に樹姿を異にする3 品種（中間型のや まかい，直立型のやぶきた，開張型のかなやみどり） 供試し， 2 年生苗を単条 $(1.8 \mathrm{~m} \times 0.3 \mathrm{~m})$ 亿定植し, 早 期成園化を図る仕立て法について検討した。

2 取り上げた要因と水準は, (1) 品種（上記の 3 品 種)，(2) 定植時の世ん枝位置（地上 $15 \mathrm{~cm}, 20 \mathrm{~cm}, 25$ cm)，(3) 2 年目のせ九枝位置（定植時のせん枝位置より $5 \mathrm{~cm}, 10 \mathrm{~cm}, 15 \mathrm{~cm})$ で, 直交表 $\mathrm{L}_{27}$ に割りつけて試 験老行った。

3 生育調查の結果, 直立型のやぶきたは樹高の伸び
がよく，株張りの搪がりは定植後 3 年目まではかなやみ どりょり遅いが，その後は，いずれの品種とす同程度で あった。開張型のかなやみどりは，樹高の伸びは遅いが 株張りの搪がりは早、。特に, 定植後 3 年目までの拡が りが大さい。やまかいはやぶきたとかなやみどりの間に あるが，やぶきた近い生育をする。

$410 \mathrm{a}$ 当たり収量は，いずれの品種す株張りとの相 関が高い。早期成園化を図るには，樹高と株張りのバラ ンスを保らつつ，早期浪株張りを拡げる必要がある。

5 せん枝位置を高くすると樹高も株張りも大きくな る。品種によって,それらの比率は異なる。

6 樹形の目安としての株張り/樹高の値を求めてみ た。直立型のやぶきたは，仕立ての段階では小さくなり 易く，開張型のかなやみどりは大さくなり易い。せん枝 位置を高くすると, 樹高や株張りは大きくなるが, 株張 り/樹高の值は小さくなる。

7 やぶきたのよ5な直立型の品種は, 株張り/樹高の 值は小さいので，その值をできるだけ大きく保ちつつ株 張りの拡大を図るのがよい。定植時のせん枝位置を高さ $15 \sim 20 \mathrm{~cm}$ とし， 2 年目のせん枝位置は，定植時のせん 枝位置から $10 \mathrm{~cm}$ 程度上げたところが適当である。

かなやみどりのような開張型の品種は, 株張り/樹高の 值が大きいので，樹高は高めにして，株張りの増大を図 るのがよい。定植時のせん枝位置を高さ $20 \sim 25 \mathrm{~cm}$ と し, 2 年目のせん枝位置は, 定植特のせん枝位置から 10 $\sim 15 \mathrm{~cm}$ 上げたところが適当である。

中間型のやまかいは，定植時のせん枝の位置を高さ 20 $\mathrm{cm}$ 程度とし，2 年目のせん枝位置は, 定植時のせん枝 の位䁂から $10 \mathrm{~cm}$ 程度上げたところが適当と思われる。

最後にこの試験を実施するに当たり，いるいると御 教示いただいた 農業技術研究所物理統計部 㻕汇正樹 調查科長, 試験設計研究室 大塚淮雄 室長, とり末とめ に当たって，愁切なるご指導を睗った䔚朴水産省茶業試 験場 中山仰栽培部長, 茶樹第三研究室 青野英也 室長，また，試験に協力いたたいた当場高林多門主幹 高橋宇正技師，倉貫幸一技師，中部農業改良晋及所谷博 司技師に厚くお礼申し上げる次第である。 


\section{6 引用文 献}

1) 田中勝夫，山下正隆，関谷直正：茶技研，No. 49 , $50 \sim 61$ (1975).

\section{Summary}

1. Methods of frame formation to shorten the period of making mature tea bush were investigated. Three different types of varieties in plant shape (Yabukita :erect type, Yamakai intermediate type and Kanayamidori :spread type) were chosen for this experiment. They were planted in single rows with an intarval of $1.8 \mathrm{~m}$ and $0.3 \mathrm{~m}$ distance between plants.

2. The design of $3^{8}$ type multi-factors was established by including 3 factors having each 3 levels. The factors and levels are as follows:

(1) Varieties: Yabukita, Yamkai and Kanayamidori.

(2) Heading height at the time of planting: 15 , 20 and $25 \mathrm{~cm}$ above the ground level.

(3) Cutting height at one year after planting: 5,10 and $15 \mathrm{~cm}$ above the heading level at the planting time.

3. Height of plant in var. Yabukita was superior to that in var. Kanayamidori, but the spread of plant was inferior during the experimental period of 5 years.

4. The yield obtained from a unit erea of tea field was increased with increase of the spread of plant. From the result, it was thought that the inerease of the plant spread balanced with the increase plant height and this was important for shortening the period of making mature tea bush.

5. In the plot in which the plants were cut at high level, both height and spread of the plants was greater than those of the other plots.

6. The ratio of spread to height of tea plant was culculated as a representation of plant shape. The ratio was low in var. Yabukita and high in var. Kanayamidori during the frame formation perid. In the plot in which the plants were cut at high level, the ratio was lower than those of the other plots.

7. From the experiment above mentioned, it is thought that the following methods are good for frame formation in each variety.

a) The plants are headed back to a height of $15-20 \mathrm{~cm}$ at the planting time, and the new growthes are cut back to a height of $10 \mathrm{~cm}$ above the previous cutting level at one year after planting for erect type variety such as Yabukita.

b) The plants are headed back to a height of $20-25 \mathrm{~cm}$ at the planting time and the new growthes are cut back to a height of $10 \mathrm{~cm}$ above the previous cutting level at one year after planting for the spread type variety such as Kanayamidori.

(Sep. 1, 1982) 